\title{
Integrating Technology in Art Education in Nigerian Education System: The Need for an Effective Pedagogical Approach
}

\author{
Bede Blaise Chukwunyere Onwuagboke* \\ School of Educational Studies, Universiti Sains Malaysia, 11800 Pulau Pinang, Malaysia \\ ${ }^{*}$ Corresponding Author Email: bbconwu@yahoo.com \\ Dr. Termit Kaur Ranjit Singh \\ School of Educational Studies, Universiti Sains Malaysia, 11800 Pulau Pinang, Malaysia \\ Email: termitk@gmail.com \\ Professor Dr. Fong Soon Fook \\ School of Educational Studies, Universiti Sains Malaysia, 11800 Pulau Pinang, Malaysia \\ Email: sffong@usm.my
}

Doi:10.5901/mjss.2015.v6n4s1p184

\section{Abstract}

Fine Art has suffered tremendous neglect in schools within and outside Nigeria due to misconstruing of the benefits of the subject by policy makers and even parents who dissuade their wards from spending time in artistic creations. Despite the lofty position which the national policy on education gave to it in the policy of Nigerian education, Fine Art is not always found in the time table of most schools. Pedagogical approaches often used by teachers have often proved inadequate leading to poor performance of students in public examinations. This paper is an exploratory conceptual study (document-based qualitative study approach). Literature is explored to determine objectives of art teaching in schools; role of art teaching in general education; need for effective art teaching model. It proposes an ICT Integrated Studio Teaching Model (IISTM) as a paradigm shift from the teacher centred approach to learner centred approach which allows learning through exposure to authentic learning experiences. The effective use of ICT in teaching as well as teacher modelling practical examples of how to solve design problems in the subject is recommended to motivate students in the studio environment.

Keywords: Technology integration; Art Education; Effective pedagogical approach; Nigerian education system.

\section{Introduction}

Prior to the coming of the Europeans to Nigeria, art has long flourished as epitomized by the classical Benin bronzes, Igbo-Ukwu, Ife terracotta, Esie soap-stone figures, and other art cultures dated many years BC. The artists normally acquire their skills through apprenticeship to the master artist. Most of the art works produced served mostly religious and cult purposes. The artist had a sacred duty to create art objects that represent the various deities venerated in their communal and private worships (Onwuagboke, 2005; 2006). Occasionally, utilitarian object for the use of the royal courts and for daily usage of the individuals in the community were commissioned and produced.

The colonization of Nigeria by Britain created vacancies in the colonial offices that required the natives to fill. These vacancies required cheap semi-skilled labor to fill as the colonial business concerns continued to grow. The Christian missions which came along with colonialism had need for interpreters and junior teachers to help in the spreading of the gospel to the natives. The above needs according to Oguibe, (2002) led to the establishment of schools by the Christian missions in Nigeria. The curriculum of these early schools established by the missionaries was more of a utilitarian one geared towards serving the purpose of evangelism with a focus on reading, writing and arithmetic (Galloway, 1960). In 1848 however there was a slight departure on the timetable from the initial three Rs to include geography with the exclusion of art education. The above scenario made Okeke, (1979) to reach conclusion that cultural and creative art education was not considered necessary for the converts by the colonial Christian mission proprietors of the early schools in Nigeria.

The neglect of art in the school curriculum can be understood from two basic angles; the first being that schools 
were mainly attended by converts and stubborn children whose parents would like to be disciplined by the teachers. The encouragement and teaching of art to the new converts who had been indoctrinated into branding their native art objects as idol and thus hating the making of such will invariably encourage them to love and thus recreate those objects which were initially destroyed in bonfire by the missionaries. Secondly the colonial masters expected an education curriculum for the colony which would encourage the development of specific skills for the service of the empire rather than the allround development of the individual which art education bestows. According to Oguibe, (2002) art and aesthetic sensibility were crucial signifiers of the civilized which constituted the gap between savagery and culture. To the colonial masters, the African was visualized as having failed to develop any high form of civilization.

The introduction of creative arts in the curriculum of the colonial schools was virtually considered a waste as noted by one George Fowler in 1938 in Aina Onabolu's visitors' book. To Fowler, teaching an African the art of the white man is not only a waste of time but also a misplacement of value. Thus in place of Art in the curriculum, aspects of crafts of the Europeans were introduced to facilitate the production of utilitarian objects for the use of the colonial missions (Lasekan, 1966, Oloidi, 2011). Despite the challenges faced in the introduction of art into the curriculum of Nigerian schools, art found its way into the schools in Nigeria through the relentless and persistent efforts of Aina Onabolu (1882-1963). Though he was not the first African to practice the art of painting and graphic arts like was the case in Renaissance Europe, he was the first in Nigeria and indeed the earliest recorded in West Africa (Oguibe, 2002). He started his art practice by teaching himself how to draw by imitating illustrations in religious and religious books (Oloidi, 1986).

Although Wangboje (1969) point to historical records of earlier attempts to introduce art into the curriculum of Nigerian school in 1897 at Hope Waddel Training Institute Calabar, Onabolu on his part made series of fruitless efforts between 1900 and 1920 to persuade the colonial education department in Nigeria to introduce art in schools. When his efforts yielded no dividend, he applied for permission to teach art in some schools in Lagos for no pay, on the advice of some head teachers, a permission that was not granted by the colonial education authorities on the ground that he possessed no formal education or certificate in art (Oloidi, 2011). Determined to succeed, he then went for the option of teaching willing and enthusiastic students on a private basis. His quest for realism in art led him to England and France where he enrolled and studied art at St John's Wood College, London between 1920 and 1922 (Oloidi,1986). Two reasons can be adduced for his sojourn in England for formal studies in art; the first according to Onabolu (1963) was to learn all he could about the science of painting, perspective, anatomy and other specializations and ancillary disciplines which are the distinguishing characteristics of European art education. Secondly, with the level of artistic skills already developed through self-tuition, he needed a teaching qualification to enable him gain entry into the colonial education system so as to obtain the much needed approval to introduce art into the Nigerian education system. It was after his return to Nigeria in 1922 that the official approval for the introduction of art in schools within and around Lagos was granted.

\section{Literature Review}

\subsection{Growth of Art in the Nigerian Education System}

By 1926 the teaching load had become too heavy for him to carry alone hence he requested the colonial education department to appoint another art teacher to relieve him of the work load. Not finding any qualified teacher within the colony, Mr. Kenneth C. Murray was brought from Britain to give Onabolu a helping hand. With the arrival of Murray in Nigeria in1927, the stage was thus set for a strengthened art training in Nigerian schools (Irivwieri, 2010). Between 1937 and 1940 the teaching activities of Murray became manifest among his students. He encouraged his student to deemphasize strict formalism in art as exemplified in the teachings and works of Onabolu.

He encouraged the creation of art works from their rural village life like fetching firewood, fetching water, climbing trees etc. as a way of preserving their cultural heritage and perpetuating their identity. Murray's opposition of the acquisition of the skills of observation and representation that Onabolu insisted on, produced a strange, new form of naive art which had little to do with the classical traditions of his pupils' backgrounds, or with the modern tendencies that were beginning to emerge as a result of the appropriation and domestication of European principles (Oguibe, 2002). Though Onabolu worked tirelessly to introduce art education into the Nigerian schools, it was Murray who took Onabolu's new art to Western and Eastern regions of Nigeria to help realize Onabolu's dream of making Western art part of Nigeria's education (Oloidi, 2011). 


\subsection{The objectives of Teaching Fine and Applied Arts in schools}

The objectives of inclusion of fine and applied arts in school curriculum at all levels of education are numerous. However the national policy on education identified two major objectives which art teaching should meet. They are:

- instruction should be geared towards the production of self-reliant, resourceful, creative people; people with initiative and understanding for the need to create; people with a positive identity in the community;

- the development of aesthetic awareness in the general public with regard to the products of industry and the environment (FRN, 2004).

The level of unemployment in the nation is such that the youth are continually encouraged to study courses that can guarantee them self-employment on graduation rather than wait on government for non-existent jobs. Fine and applied arts aptly fits into the frame of reference of such courses especially if the prescribe teaching modes are followed in its teaching. Every individual that passes through art experiences is not expected to practice art however going through art experiences no doubt will engender the development of aesthetic awareness in the generality of the citizenry for a better environmental consciousness and awareness. Such individuals are equipped with valuable tools to make informed decisions concerning aesthetic matters.

\subsection{Role of Art teaching in General Education}

Despite the neglect suffered by art in our education systems, its contribution to the educational development of an individual is immense and not an issue of debate. There is no doubt that art can make substantial contributions to students learning. Arts are veritable tools for expressing ideas, concepts and feelings and a vehicle of communicating with others (Dixon \& Senior, 2009; Lind, 2007; Russell-Bowie, 2007).

Graphic design which is one of the branches in Fine Arts has often been referred to as visual communication design. One area where the knowledge from graphic design is very useful is in classroom communication. The process of learning in any subject area most often requires visuals and illustrations to enhance communication of the message (Enamhe, 2013) so as to enable learners to concretize abstract concepts thereby enabling retention of concepts so learned. A study carried out by Ajibade and Elemi, (2012) shows that visuals used in the teaching of student led to a significantly better achievement than teaching conducted without visuals. Teaching and learning is a complex process that can be enhanced and reinforced with visuals and illustrations which stimulates, motivates and at the same time arrest learners' interest. According to Ajakey, (1982) fine art is highly correlated to other school subjects in that it influences their successful teaching through the creation of graphic illustrations.

Art education can be said to be at the heart of development of visual literacy which is one of the literacies required for individuals to function effectively in the $21^{\text {st }}$ century society. Art has a very crucial role to play in preparing students as visually literate and critical members of the society (Brown, 2002; Schwartz, 1991). It develops in the learner, the necessary imaginative, intellectual, theoretical and practical skills and competencies for continued personal and professional development (Ajibade, Enamhe \& Oloidi, 2011). Art instructions if carried out appropriately enables the learners to be creative and critical thinkers thereby making them to become self-confident, self-governing and contributing members of the society who can articulate and solve problems in many ways.

\subsection{The state of Fine Art in the curriculum of Nigerian Education}

Following the introduction of art in the curriculum of Nigeria educational system in 1922, the Nigeria National policy on education recognizes the subject as one of the subjects to be taught at primary, secondary and tertiary levels of her educational system (FRN, 2004). In the primary school curriculum, Fine art is subsumed in Cultural and creative arts. The document prescribed that instruction shall be carried out using practical, exploratory and experimental methods. At the secondary level, it is grouped as pre-vocational electives along other subjects like Agriculture, Business Studies, Home Economics, Local crafts and Computer education with emphasis on practice rather than theory (FRN, 2004). The policy gave freedom to institutions at the tertiary level to decide what subjects to teach, a decision that must be guided by national goals. From the foregoing, fine art teaching methods should be more of exploratory, practical and experimental without excluding other methods that have theoretical backing to help learners to create knowledge. The society and indeed the schools place so much premiums on literacy and numeracy giving little or no time for arts (Russell-Bowie, 2006) hence in most schools art is rarely found in the school timetable(Onwuagboke, 2002). This has painted an ugly picture that scares away talented young men and women from art related careers.

Technology has virtually transformed the way we live and go about our daily activities. Its influence can be felt in 
almost all facet of human endeavor whether political, socio-economic, religious, sports and recreation. One of the areas that technology is used to improve activities is in the classroom. With the acceptance of computers as required teaching and learning tools in the classroom at all levels all over the world, the stage was set for its use in the Fine Arts classroom. Regrettably, this is not yet fully realized as a result of problems facing effective integration of technology into teaching and learning in a developing country like Nigeria. This problem ranges from lack of ICT infrastructure at all levels of Nigerian education system; inadequate electric power supply; lack requisite technological and pedagogical competences on the part of the teachers to lack of knowledgeable technical support staff. The result of this scenario is that technology is rarely applied in the teaching and learning of fine Art even when the curriculum stipulates that it should be used. This is partly because of the level of development in the country and mostly due to the neglect that has globally been the case of Fine Art as a subject.

Evidences abound on the neglect art suffers in schools across the globe. For instance art is marginalized in Australian schools (Gibson \& Anderson, 2008) resulting in lack of confidence, skills adequate training and resources. When there is need for budget cut in schools, the art program is the worst hit by such a cut in budget. For example Hawkin (2012), state that art programs in many schools in America were forced to close as a result of budget cut. In Nigeria despite the fact that the foundation for art in the Nigerian educational system has been laid in the Nigeria National policy on education, art is however neglected in the curriculum at all levels of Nigeria education system (Aladejana and Idowu, 2009).

The teaching of the subject is characterized by lack of well-equipped art studios, instructional resources for effective teaching and qualified teachers (Onwuagboke, 2002; Adeyanju, 2003). The result of the above scenario is poor performance of students in the subject at secondary school level (Owokade, 2006; Okonofua and Ekpo, 2012) and a subsequent low rate of admission into art related careers in the tertiary institutions (Irivwieri, 2009; Okonofua and Ekpo, 2012). This situation is further compounded by the fact that teaching fine arts in the schools is devoid of learning theories and teaching models (Harwood, 2007; Okonofua and Ekpo 2012) leading to the predominance of lecture methods (Alter, 2010; Bada and Fadare, 2002; Aladejana, 2006, Ametordzi, Osei-Poku and Eshun, 2012 ). This observed neglect of the subject will continue unabated may likely lead to the disappearance of the subject from schools if timely actions are not taken to reposition art in the curriculum of schools at all levels.

\subsection{Need for effective teaching model for technology integration}

To enable the art programs in our schools to develop visual literacy which is a key $21^{\text {st }}$ century skill in the learners, there is the need for teachers to approach their job armed with well-designed teaching models based on tested instructional design principles stems from the fact that teaching is a complex job. Adopting the teacher-centered traditional lecture method prevalent in schools will definitely fall short of expectation as it poses no challenge to students' critical thinking skills. The complexity of the teaching job emanates from the fact that no single action amounts to good teaching. It requires a combination of many factors and resources organized through systematic planning to achieve result.

The adoption of technology in the learning environment has been variously canvassed as the panacea and found to increase students' performance in many course offerings including fine arts (Aladejana and Idowu, 2009; Abbass, 2011; Appiah and Cronje, 2013). However, it has also been said that it has the tendency of hindering learning if inappropriately used in the classroom (Bransford, Brown and Cocking, 1999). This goes to underscore the fact that technology alone may not be able to account for the needed educational transformation expected in present day art classroom without a well-planned instructional event based on sound instructional design principles. The effectiveness of any technology based instruction is highly dependent on the manner in which the teacher integrates ICT in a way that learning is enhanced (Allen, Pianta, Gregory, Mikami and Lun, 2011). If the instructional process is designed following sound instructional principles to integrate ICT, then the expected outcome will be enhanced. To this end therefore the authors propose a teaching model that integrates technology into art teaching in such a way that learning will be enhanced.

\section{Materials and Methods}

The study was carried out basically as a literature based conceptual study. The study involved the use of documentbased qualitative approach drawing data from mainly two sources. In the first instance, policy documents on the place of Art in the Nigerian school curriculum were used. Secondly, the study considered existing literature relating to fine art teaching within and outside Nigeria. The reason why Art teaching outside Nigeria was considered in this study stems from the fact that Fine Art suffers the same fate in virtually all countries of the world whether developed or developing. 


\section{Findings and Discussion}

Findings from this study have revealed that Nigerian educational policy is favourably disposed to art teaching as enshrined in the document. Scholars have also expounded the various roles art plays in the teaching and learning environment. However this favourable disposition of the policy has not translated in reasonable ways to the expected growth of the subject in the school system as a result of the neglect the subject has been suffering in the hands of education administrators and uniformed parents. The subject is expected to be taught using strategies that allow for practical demonstration of skills, exploration of ideas, images and visual art forms as well as experimentation. These teaching approaches are rarely used as the teachers resort to only theoretical teaching at the expense of practice. This situation has been seen as the reason for poor performance of students in public art examinations. With the introduction of the use of computers in learning, it therefore follows that art teachers should integrate it into their teaching as a matter of necessity. This is however difficult as most of the teachers learnt how to teach art manually without technology.

The need to improve fine art instruction in schools to ensure better performance of students in the subject so as to minimize numerous problems facing art teaching (Alter, 2010) that can be addressed through better instructional methods has been stressed. Art praxis is not a solely theoretical affair as practiced in most schools (Ogundiyule et al., 2008). For all-round development of the individual learners, instruction in the visual art and indeed other studio oriented subjects should strike a balance between the practical and the theoretical aspect of the subject (Arslan, 2012). To accomplish a sound instruction in the subject, much is required of the teacher at any education level. A framework for integrating ICT in studio teaching for effective instructional delivery is presented in this paper.

\subsection{Framework for ICT integration in fine arts teaching}

Effective instruction is not just a matter of standing or sitting in front of a class and dishing out information to a group of students whose heads are perceived as empty and therefore required to be filled. Instruction requires adequate preparation and planning in terms of how to combine artistic knowledge and skills (AKS), pedagogical knowledge and strategies (PKS) and technological knowledge and Skills (TKS) to effectively present the instructional content in a learning situation so as to enhance the learners' achievements. Designing a good instructional event in fine art entails that the teacher should possess certain knowledge, skills and competencies in the subject area (AKS), teaching methods (PKS) and technological knowledge and skills (TKS) to make decisions and selection of required knowledge and skills appropriate to solve a given learning problem. The artistic knowledge and skills which the teacher should have and consider in planning instruction include subject content, goals and instructional objectives, design principles as well as artistic creative process and skills. In terms of pedagogical knowledge and skills, the teacher should be armed with knowledge of learning theories and processes, teaching methods and strategies, learners' characteristics and the learning environment. Technologically knowledge of hardware and software as well as soft skills is required. The teaching framework is represented diagrammatically in figure 1.

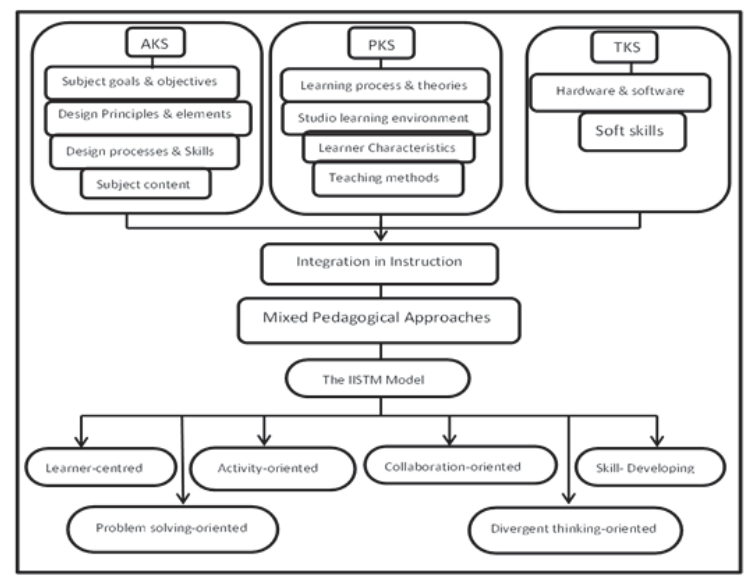

Figure 1: ICT Integrated Studio Teaching Framework 
Such instruction should involve the use of the proposed ICT integrated studio teaching model (IISTM).

\subsection{ICT integrated studio teaching model (IISTM)}

The model has five phases of instructional events of "inspire", "demonstrate", "explore", "Implement", and "critique" using a mixed pedagogical approach as depicted in figure 2 .

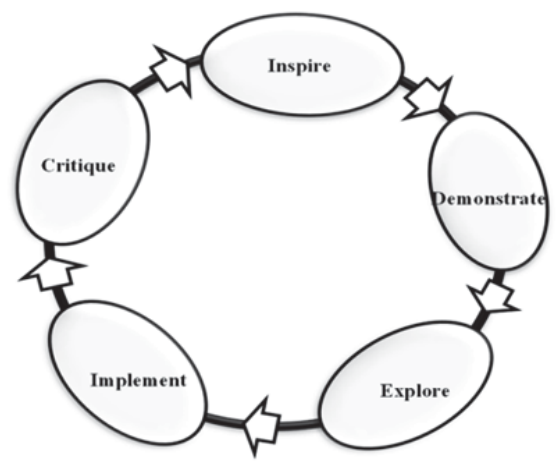

Figure 2: ICT Integrated Studio Teaching Model (IISTM)

\subsubsection{Inspire}

The design problem or the topic of the lesson is introduced at the beginning of the instructional event. This is the problem the teacher wants to address using the instructional intervention. It is this problem with varying potential for creative processing that triggers of the motivation to engage in an artistic activity (Koster, 2001). The problem should be structured and presented in a manner that "ill-defined" challenges the learner to think critically and divergently using various problem solving methods so as to find solutions. Such a problem is one in which there is no ready-made, best explanation or representation and no standard method of finding solution. Technologies can be effectively integrated at this phase to present information to the learner like use of power point presentation which may be video, images or both. The purpose of this may be motivational, inspirational as well as information giving.

The design problem is presented together with the theoretical part of the topic of the lesson that will lead to the practical design. The learners may also be referred to the internet for information searching on the topic which can later be discussed in the class. Briefs on the design requirements are also made to enable students to initiate dialogue with the teacher/instructor. Examples of the anticipated finished products can be displayed for students to get them further motivated and inspired. According to Okonofua and Ekpo, (2012) showing the students some works of art will help them concretize the abstract concepts of the intended exercise. Caution should however be exercised at this point so that the students do not see the model used to show example as the correct answer to the design problem.

\subsubsection{Demonstrate}

In a technology oriented studio learning environment, this phase of the teaching model should be practically-oriented and technology-driven. As the use of hardware and software tools are involved in finding solution to the problem, which the students may not be able to use despite the fact that they have been taught computer graphics in their previous class. This is against the background that previous teachings of computer graphics has been theory oriented. This being the case, there is the need to bring in a computer graphic expert to demonstrate the required skills for the teacher and the learners (van Merrienboer \& Kirschner, 2007). The learners have to hear the problem discussed, see how solutions can be achieved using ICT tools and finally try out solutions to identified problem. This is hinged on Confucius, $\left(551^{\mathrm{BC}}-479^{\mathrm{BC}}\right)$ popular saying "I hear and I forget, I see and I remember, I do and I understand". 


\subsubsection{Explore}

This stage is designed to spur the students to explore the library, Internet and design websites for content, images and further inspiration. Research on the topic as well as visuals and fonts suitable for managing solution to the problem is necessary. According to Loewy, (2008) research is a very crucial part of design teaching in that good research is seen as an essential ingredient to making a successful design. This activity can be group or individual activity which is coordinated and monitored by the teacher. Group activities will be more suitable for teaching art at the lower level of education where emphasis is not on the students' artwork but on the artistic processes involved. The aim is to acquaint the learner with information and current trends in the area to enable the creation of solutions that are in tandem with and yet distinct from other solutions to similar design problems.

Quickly sketching the ideas and inspirations as they occur to the learner from the introduction by the teacher and the researches on the internet is good practice and must be encouraged. This is because drawing helps to define thoughts that might never be realizes if not committed to representation. Design communication suffers without drawing, both between designers and within an individual designer (Loewy, 2008). It is a vehicle for creative interchange in group sessions enabling designers to share and stimulate ideas (Schenk, 1991).

\subsubsection{Implement}

At this stage the learner is expected to go ahead to implement design solutions to the design problems using computer and graphic software. A thumbnail design prepared at the exploration stage and approved by the jury for final production is produced. More learning occurs as the learner carries on with design process in constant consultation with the teacher and his/her peers for critiquing and further direction if need be. The implementation stage thus becomes a flexible process with the use of computer software as elements of design can be arranged and rearranged without problems.

\subsubsection{Critique}

With the aid of multimedia projectors, finished design are presented for whole group critiquing and assessment. The critique given to an individual's design serves as an inspiration for both the designer and peers. Such new inspirations are used to review the work or kept for use in subsequent jobs as critiquing remains the core pedagogical approach used in art studio (Graham, 2003). The final critiquing is for the student to get the final feedback which stands for summative evaluation of the design activity. Bartel, (2012) advocates for empathic critique sessions which he maintains are not competitive but rather collaborative. He sees the critique as a hunt for visual effects, meaning, purpose and new ideas in which participants are acting in their own best interest by being naturally helpful selves thus replacing competition with mutual discovery. It offers opportunities for reflections on the part of the learner on the learning experience that has been undertaken in line with Kolb's experiential learning.

The final critique and assessment though summative at this stage becomes formative in the design learning process. The experience the learner acquires during the just concluded design process forms a concrete experience for further reflections which he will fall back to when tackling design problems in the future thereby continuing on the experiential cycle of Kolb. Learning in graphic design occurs from a limited number of assignments. It is not usually possible to expose the learners to every type of design problem in the learning environment hence the need for "high road" and "low road" transfer of learning. Perkins and Salomon, (1989) describes "high road" transfer of learning as the ability of the learner to apply knowledge gained from the design activity in a different context whereas refers to the use of the learned skills in similar contexts as "low road" transfer. High road transfer is most desirable going by the above that all types of design problems will not be handled during the classroom teaching and learning.

\section{Conclusion}

The pervasiveness of technology in the present information age has warranted its use in virtually every field of human endeavour. Most jobs performed manually in the past have been automated as a result of technological development. The education enterprise has keyed into harnessing these developments for the enhancement of learning outcomes. The learning of Fine Art is one of such enterprises in education that has a high propensity of integrating technology in its praxis. However the age long neglect suffered by the subject coupled with the paucity of technological infrastructure at all levels of our educational system has made it difficult to reap the benefits of technology enhanced classroom.

This paper therefore proposed a five-phased teaching model that will enable art teachers to seamlessly integrate 
information and communication technology in the art studio teaching. It has a view of creating a learner centred learning environment which focuses on skills development, problem solving as well as collaboration oriented. Adopting the model in teaching will create a learning situation that encourages the learner to experiment and explore various solutions to creativity problems thereby developing their visual literacy while enhancing their critical thinking capacities. This would ultimately enhance their learning achievement and reduce the poor performance syndrome in the subject in public examinations.

\section{References}

Abass, B. T. (2011). Computer Instructional Approach and Students' Creative Ability in Sculpture Education in Nigeria Universities: Obafemi Awolowo University as a Case Study. World Journal of Education, 1(2), 130-135.

Adeyanju, J. L. (2003) Teachers' Perception of the Effects and Use of Learning Aids in Teaching: a case study of Winneba basic and secondary schools, Ultibase, November. http://ultibase.rmit.edu.au/Articles/nov03/adeyanju1.htm

Ajakeye, G. (1982). Questions and answers on art and crafts for teachers: Grade I/ Certificate Examination. Ekiti, Nigeria: Omolaya Press.

Ajibade, B. and Elemi, N. (2012), "The Importance of Visual illustrations in Recommended Primary and Secondary School textbooks in Calabar," Journal of Educational and Social Research, 2(1), $161-170$.

Ajibade, B., Enamhe, B. B. and Oloidi, W. (2011), "Is fine arts inevitable requisite for bachelor's degree in visual arts?: Notes from the admission policy of a Nigerian university," Mediterranean Journal of Social Sciences, 2(3), 203 - 212.

Aladejana, F. (2006). Concept of Teaching 1. In O. J. Ehindero and F. O. Aladejana (Eds) Introduction to the teaching profession. Lagos: Literamed Publications Ltd, 12-19

Aladejana, F., \& Idowu, L. (2009). Using a Computerised Graphics Package to Achieve a Technology-Oriented Classroom. Policy Futures in Education, 7(4), 439-444.

Allen, J. P., Pianta, R. C., Gregory, A., Mikami, A. Y., \& Lun, J. (2011). An interaction-based approach to enhancing secondary school instruction and student achievement. Science, 333(6045), 1034-1037.

Alter, F. (2010). Using the visual arts to harness creativity: UNESCO Observatory, 1 (5)

Ametordzi, S., Osei-Poku, P. \& Eshun, E.F. (2012) Pedagogical Situations and Learning out-comes in graphic design in selected Senior High Schools in Kumasi Metropolis of Ghana. International Journal of Innovative Research and Development. 1(9)

Appiah, E. \& Cronje, J. (2013) Information Communication and Technology (ICT) and the Challenges of Ideation in Graphic Design: An Activity Theory Focus, International Journal of Computer Applications. 63(6), 13-23.

Arslan, A. A. (2012). An Analysis of Teaching Methods Used at the Course of Basic Design. Procedia - Social and Behavioral Sciences. $51,172-176$

Bada, T. and Fadare, O. (2002). Graphic Arts. llesa: Onibonoje Press.

Bartel, M. (2012). Art Rubric - an artwork assessment form. Retrieved 1st November, 2013 from http://www.goshen.edu/art/ ed/rubric2.html

Bransford, J. D., Brown, A. L., \& Cocking, R. R. (Eds.). (1999). How people learn: Brain, mind, experience, and school. Washington, D.C.: National Academy Press.

Brown, I. (2002). New radicalism for art education: Embracing change. Australian Art Education, 25(1), 62-64.

Dixon, M., \& Senior, K. (2009). Traversing theory and transgressing academic discourses: Arts-based research in teacher education. International journal of education and the arts, 10(24). Retrieved January, 27 2014, from http://www.jijea.org/v10n24/.

Galloway, A.D. (1960). Missionary Impact on Nigeria. Nigeria Magazine, Special Issue.

Gibson, R., \& Anderson, M. (2008). Touching the void: Arts education research in Australia. Asia Pacific Journal of Education, 28(1), 103-112.

Graham, E. M. (2003). Studio design critique: student and faculty expectations and reality (M.L.A. Thesis) Department of Landscape Architecture, Louisiana State University, USA.

Graham, C. R. (2006). Blended learning systems: Definitions, current trends and future directions. In C. J. Bonk \& C. R. Graham (Eds.), The handbook of blended learning: Global perspectives, local designs (pp. 3-21). San Francisco: Pfeiffer.

Harwood, E. (2007). Artists in the academy: Curriculum and instruction. In L. Bresler (Ed.), International Handbook of Research in Arts Education (pp. 313-329). Dordrecht: Springer.

Hawkin, T. (2012). Will less art and Music in the classroom really help students soar academically? Retrieved April 182014 from http://www.washingtonpost.com/blogs/therootdc

Irivwieri, G. O. (2009). The Implementation of the Creative Arts Curriculum in Secondary Schools in Nigeria. African Research Review, 3 (3), 342-358

Kolster, J. (2001). Bringing Art into the Elementary Classroom. Wadsworth: Thompson Learning, USA.

Loewy, A. F. (2008). Teaching design innovation: Methods for promoting innovation in the university industrial design studio.

Lasekan, A. (1966). Western Art on African Shores. Unpublished Manuscript. University of Nigeria, Nsukka.

Lind, M. (2006). Why the liberal arts still matter. The Wilson Quarterly (1976- ), 30(4), 52-58.

Nigeria, F. R. (2004). National Policy on Education. Yaba Lagos: NERDC (Nigerian Educational Research and Development Council) Press. 
Oguibe, O. (2002). Appropriation as nationalism in modern African art. Third Text, 16(3), 243-259.

Ogunduyile, S. R., Kayode, F., \& Ojo, B. (2008). Art and design practices in Nigeria: The problem of dropping out. International Journal of Education \& the Arts, 9(4), 1-21

Okeke, U. (1979). History of Modern Nigerian Art. Nigeria Magazine.

Okonofua, A. U. \& Ekpo, M. C. (2012). Effect of Kolb's Experiential Learning Theory and Model (KELT\&M) on Learning of Fine Art and Praxis in Uyo Secondary Schools, Nigeria. Arts Education at the crossroad of cultures, 540-552.

Oloidi, O. (1986). Constraints on the Growth and Development of Modern Nigerian Art in the Colonial Period. Arts Faculty Seminar. University of Nigeria, Nsukka

Oloidi, O. (2011). The Rejected Stone: Visual Arts in an Artistically Uninformed Nigerian Society. Inaugural Lecture, University of Nigeria Nsukka, Nigeria.

Onabolu, D. (1963). Aina Onabolu. Nigeria Magazine, 79.

Onwuagboke, B. B. C. (2005). African Art Forms and Religious Worship, In G. Ajileye (Ed.) Humanities and African Development (pp.6087). Owerri: Taurus publications.

Onwuagboke, B.B.C. (2006). The Role of Art in Religious Worship in "NKA" A journal of the School of Arts A.I.C.E. Owerri. (5), 7986.

Onwuagboke, B. B. C. (2002). Availability and Utilization of Instructional Materials for Teaching Fine Arts in Secondary Schools in Owerri Educational Zone. M.Ed., Imo State University, Owerri.

Owokade, O. O. (2006). Facilitating effective Performance of Students in Mathematics, Science and Technology in Secondary Schools. Federal Government of Nigeria-UNESCO Workshop for Inspectors. University of Lagos.

Perkins, D. N., \& Salomon, G. (1989). Are cognitive skills context-bound?. Educational Researcher, 18(1), 16-25.

Russell-Bowie, D. (2006). MMADD about the arts: An Introduction to primary arts education, Frenchs Forest: Pearson Education Australia.

Schenk, P. (1991). The role of drawing in the graphic design process. Design Studies, 12(3), 168-181.

Schwartz, B. (1991). The power and potential of laser videodisc technology for art education in the 90's. Art Education, May, 9-17.

Van Merrienboer, J. J. G. \& Kirschner, P. A. (2007). Ten steps to complex learning: A systematic approach to four-component instructional design. Mahwah, NJ: Erlbaum.

Wangboje, S. (1969). Some Issues on Art Education: The Nigerian Experience. INSEA International Society for Education through Art. Humanism in a Technological Age, 74-84. 